\title{
Respon Tiga Varietas Ubi Kayu (Manihot esculenta. L) Terhadap Pemupukan di Kutai Timur
}

\author{
Ratna Shanti ${ }^{1}$ dan Ratna Nirmala ${ }^{2}$ \\ 1,2 Program Studi Agroekoteknologi, Fakultas Pertanian, Universitas Mulawarman Jl. \\ Pasir Balengkong Kota Samarinda, Kalimantan Timur 75117 \\ 1Email: ratnasanti.msi@gmail.com, \\ 2ratnanirmala1948@yahoo.co.id
}

\begin{abstract}
Growth and production of cassava plants in East Kalimantan is still low. This condition is due to relatively low soil fertility and genetic sources of cassava varieties used instead of superior varieties. While the exporter's demand for raw materials as processed products and bioethanol is so high that research needs to be done by using fertilizer and superior varieties. The purpose of this study to determine the effect of fertilization on the production of three varietas of cassava that is Kasesat, Darul Hidayah and Gajah. The field experiment was conducted for 9 months starting from March to December 2017. Locations trial in Sangata Selatan, District Kutai Timur. The design is split plot design arranged in a factorial treatment was repeated 3 times $(R)$ Treatment Varieties $(V)$ as a main plots and fertilizer treatments $(P)$ as subplot. The results showed that in organic and organic (bokashi) and there combonations capable of producing tubers each, 39.7 ton per hectares, 40.37 ton per hectares and 50.41 ton per hectares. Fertilization treatment of three varieties cassava tubers can increase production $14.41 \%, 22.52 \%$ and $52.99 \%$ respectively as a compared with kontrol. Among three varietie of cassava not significantly effect. Gajah varietie relatif high production $11.73 \%$ as a compared with both varieties.
\end{abstract}

Keywords: Growth and production of three cassava varieties, NPK fertilizer, Chicken manure fertilizer.

\begin{abstract}
ABSTRAK
Pertumbuhan dan produksi tanaman ubi kayu di Kalimantan timur masih rendah. Keadaan ini disebakan kesuburan tanah yang relatif rendah dan sumber genetik varietas ubi kayu yang dipakai bukan varietas unggul. Sedangkan permintaan eksportir terhadap bahan baku sebagai olahan hasil dan bioetanol sangat tinggi sehingga perlu dilakukan penelitian dengan menggunakan pupuk dan varietas unggul. Tujuan penelitian ini adalah untuk mengetahui pengaruh pemupukan terhadap pertumbuhan dan produksi tiga varietas ubi kayu yaitu Kasesat, Darul Hidayah, dan Gajah. Percobaan lapangan dilakukan selama 9 bulan mulai dari bulan maret hingga desember 2017. Lokasi penelitian di Sangatta Selatan, Kabupaten Kutai Timur. Percobaan ini menggunakan rancangan split plot (petak terpisah) yang disusun secara factorial, diulang sebanyak 3 (tiga) kali (R). Petak utama (PU) adalah varietas yaitu v1 (Kasesat), v2 (Darul Hidayah), dan v3 (Gajah). Anak petak adalah pupuk (P) yang terdiri dari P0 (Tanpa pupuk /control), P1 Pupuk Anorganik (800 Kg NPK/Ha), P2 Pupuk Organik (20.000 Kg Bokashi pupuk kandang ayam / Ha), P3 Kombinasi pupuk anorganik (800 $\mathrm{Kg} \mathrm{NPK} / \mathrm{Ha})$ + pupuk organik $(20.000 \mathrm{Kg}$ bokashi pupuk kandang ayam / Ha). Hasil penelitian menunjukkan bahwa pupuk anorganik dan organic (bokashi) dan kombinasinya mampu menghasilkan umbi masing-masing 39,7 ton/ $\mathrm{Ha} ; 40,37$ ton/ $\mathrm{Ha}$; dan 50,41 ton/Ha. Perlakukan pemupukan 3 varietas ubi kayu dapat meningkatkan produksi 14,41\%; 22,52\%; dan 52,99\% dibandingkan dengan control. Diantara 3 varietas ubi kayu tidak berpengaruh nyata. Varietas Gajah relative tinggi produksinya sebesar $11,73 \%$ dibandingkan dengan kedua varietas lainnya.
\end{abstract}

Kata Kunci: Pertumbuhan dan Produksi 3 Varietas Ubi Kayu, Pupuk NPK, Bokashi Pupuk Kandang Ayam 


\section{Pendahuluan}

Lahan di Kalimantan Timur didominasi oleh jenis tanah Ultisol yang sudah lanjut perkembangan tanahnya, dengan sifat kimia, fisik dan biologi tanah sudah banyak mengalami degrdasi. Akibatnya kesuburan dan produktivitas lahan rendah.

Produktivitas lahan di Kalimantan Timur dapat ditingkatkan melalui pemupukan anorganik dan organic. Pupuk anorganik dapat menambah ketersediaan unsure hara (Hardjowigeno, 2007). Pupuk organic dapat memperbaiki sifat kimia tanah (ketersediaan hara), fisik tanah (struktur, permeabilitas, meningkatkan air tersedia), dan memperbaiki sifat biologi tanah (Aritonang dan Lasiwa, 2011).

Ubi kayu merupakan salah satu tanaman pangan umbi - umbian yang mudah dijual sebagai mata dagangan (cash crop). Ubi Kayu juga dapat diolah menjadi starch (pati) relatif tinggi, gaplek, tepung ubi kayu, etanol, gula cair, surbisol, monosodium glutamat, tepung aromatik, dan pakan ternak (pelet). Potensi Ubi Kayu sebagai bahan baku etanol setiap panen 50 ton menghasilkan 7000 l/ha/th etanol (Rama Prihandana dkk, 2007). Di Cina Ubi Kayu dapat dimanfaatkan sebagai bahan pembuat pakaian, bahan fiber, dan pulp (Kimaryo et al 2000 dan Yibo et al, 2010).

Ubi Kayu dapat digunakan sebagai bahan baku bioetano. Bioetanol juga mampu meningkatkan bilangan okton dan mengurangi aditif bersimbol $(\mathrm{Pb})$ yang berbahaya terhadap lingkungan hidup (Rama Prihandana dkk, 2007). Membudidayakan energi berarti mengatasi sekaligus masalah seperti krisis energi, membuka lapangan kerja baru, mengentaskan kemiskinan, menyelamatkan devisa, jutaan hektar lahan kritis menjadi potensial dan dapat menyelamatkan bumi dari dampak emisi gas rumah kaca ("green house effect") (Rama Prihandana dkk, 2007).

Mengingat Kalimantan Timur mempunyai potensi yang besar untuk mengembangkan tanaman Ubi Kayu sebagai sumber karbohidrat, gaplek, bahan baku bioetanol, maka berdasarkan uraian diatas Perhimpunan Persahabatan IndonesiaTiongkok (PPIT) berinisiatif menyusun program sebagai mediator agar Pemerintah Indonesia, khususnya provinsi Kalimantan Timur dapat berperan sebagai pemasok bioenergi yang berasal dari komoditas ubi kayu (Manihot esculenta), sedangkan pemerintah Tiongkok berperan sebagai konsumen dalam bentuk bahan baku setengah jadi (gaplek). Harapan kedepan PPIT bisa mengekspor keunggulan komparatif Sumber Daya Alam (SDA) Kalimantan Timur agar dapat menarik investor asing untuk berinvestasi di Kalimantan Timur untuk menangani industri hulu ke hilir dan juga meningkatkan dan pengembangan ekonomi kerakyatan yang ada pada sasarannya mensejahterakan masyarakat Kalimantan Timur.

Berdasarkan uraian diatas maka dalam upaya peningkatan produktivitas lahan, dilakukan penelitian. Tujuan penelitian ini untuk mengetahui pertumbuhan dah produksi 3 
varietas ubi kayu (Manihot esculenta. L) dengan pemberian pupuk majemuk NPK (ponska) dan bokashi pupuk kandang ayam.

\section{Bahan dan Metode}

Penelitian ini dilaksanakan selama 9 bulan yaitu mulai Maret - Desember 2017. Lokasi percobaan di lahan pertanian wilayah Kecamatan Sangata Selatan, Kabupaten Kutai Timur. Bahan yang digunakan stek dari 3 varietas Kasesat, Darul Hidayah dan Gajah. Pupuk yang digunakan adalah pupuk majemuk NPK (Ponska) dan pupuk organik (Bokashi pupuk kandang ayam) serta bahan-bahan lainnya seperti EM4, Gula pasir, Dedak, Sekam, Pupuk kandang, dan air.

Penelitian ini merupakan penelitian factorial dengan 2 faktor yang disusun menggunakan rancangan Petak Terpisah (Spit Plot Design) dengan 3 kali Ulangan (R). Petak utama (PU) adalah varietas yaitu v1 (Kasesat), v2 (Darul Hidayah), dan v3 (Gajah). Anak petak adalah pupuk (P) yang terdiri dari P0 (Tanpa pupuk/control), P1 Pupuk Anorganik (800 Kg NPK/Ha), P2 Pupuk Organik (20.000 Kg Bokashi pupuk kandang ayam / Ha), P3 Kombinasi pupuk anorganik (800 Kg NPK/Ha) + pupuk organik $(20.000 \mathrm{Kg}$ bokashi pupuk kandang ayam /Ha).

Parameter yang diamati adalah data tanah dan data tanaman. Data tanah terdiri dari sifat kimia seperti pH, Organik Carbon, $\mathrm{N}$ total, C/N Ratio, P2O5, K2O, Kation Asam, Kation basa ( $\mathrm{Ca}, \mathrm{Mg}, \mathrm{K}, \mathrm{Na}$ ), KTK. Data tanaman meliputi tinggi tanaman, analisa jaringan tanaman, berat umbi ubi kayu dan berat biomassa (batang+daun) per $\mathrm{Ha}$.

\section{Hasil dan Pembahasan}

\section{Hasil Analisis Sifat Kimia}

Hasil-hasil analisis beberapa sifat kimia lokasi penelitian tercantum dalam Tabel 1

Tabel 1. Analisis sifat kimia tanah

\begin{tabular}{|c|c|c|c|c|c|c|c|c|c|c|c|c|c|c|}
\hline \multicolumn{2}{|c|}{ Kode } & $\mathrm{pH}$ & OC & $\begin{array}{c}\mathrm{N} \\
\text { Total }\end{array}$ & $\begin{array}{c}\mathrm{C} / \mathrm{N} \\
\mathrm{RASIO}\end{array}$ & \multirow{3}{*}{$\begin{array}{c}\mathrm{P}_{2} \mathrm{O} \\
5 \\
\mathrm{ppm} \\
\mathrm{P}\end{array}$} & \multirow{3}{*}{$\begin{array}{c}\mathrm{K}_{2} \mathrm{O} \\
\mathrm{ppm} \\
\mathrm{K}\end{array}$} & \multicolumn{2}{|c|}{$\begin{array}{c}\text { KATION } \\
\text { ASAM }\end{array}$} & \multicolumn{4}{|c|}{ KATION BASA (Ph 7) } & \multirow[t]{2}{*}{ KTK } \\
\hline \multirow{2}{*}{ Lapangan } & \multirow{2}{*}{ Lab } & \multirow{2}{*}{\multicolumn{4}{|c|}{$\%$}} & & & $\mathrm{~A}^{3+}$ & $\mathrm{H}^{+}$ & $\mathrm{C}^{++}$ & $\mathrm{Mg}^{++}$ & $\mathrm{K}^{+}$ & $\mathrm{N}^{+}$ & \\
\hline & & & & & & & & & II & \multicolumn{4}{|c|}{ Meq/100 g } & \\
\hline v1p0 & 8098 & 3,91 & 1,55 & 0,11 & 14 & 7,4 & 30 & 4,5 & 2,2 & 1,36 & 0.08 & 0,10 & 0,24 & 10,5 \\
\hline v2p0 & 8099 & 3,94 & 1,59 & 0,10 & 15 & 8,2 & 34 & 4,4 & 2,0 & 1,40 & 0,10 & 0,11 & 0,22 & 11,2 \\
\hline v3p0 & 8100 & 3,95 & 1,56 & 0,09 & 17 & 8,0 & 31 & 4,3 & 2,2 & 1,42 & 0,10 & 0,09 & 0,21 & 10.9 \\
\hline v1p1 & 8101 & 3,96 & 1,70 & 0,18 & 9 & 30 & 29 & 4,0 & 2.2 & 1.58 & 0,12 & 0,15 & 0,24 & 13.9 \\
\hline v2p1 & 8102 & 4,00 & 1,82 & 0,16 & 11 & 28 & 34 & 3,9 & 2.0 & 1.60 & 0,18 & 0,24 & 0,25 & 15.4 \\
\hline v3p1 & 8103 & 4,05 & 1.79 & 0,16 & 11 & 32 & 32 & 3,5 & 1,9 & 1.62 & 0.16 & 0,20 & 0,27 & 14.6 \\
\hline v1p2 & 8104 & 4,04 & 1,69 & 0,20 & 8 & 42 & 35 & 3,0 & 2.0 & 1.72 & 0,24 & 0,15 & 0,23 & 18.6 \\
\hline v2p2 & 8105 & 4,12 & 1,75 & 0,21 & 8 & 40 & 36 & 3,0 & 1,9 & 1.75 & 0,26 & 0,20 & 0,25 & 19.5 \\
\hline v3p2 & 8106 & 4,10 & 1.77 & 0,19 & 9 & 45 & 39 & 3,2 & 1,8 & 1.80 & 0.26 & 0,21 & 0,26 & 20.4 \\
\hline v1p3 & 8107 & 4,22 & 1,72 & 0,18 & 9 & 72 & 69 & 3,2 & 2,0 & 1,95 & 0,28 & 0,27 & 0,26 & 18.8 \\
\hline v2p3 & 8108 & 4,31 & 1,78 & 0,20 & 8 & 67 & 65 & 3,0 & 1,8 & 1,96 & 0,29 & 0,30 & 0,28 & 20,1 \\
\hline v3p3 & 8109 & 4,26 & 1,82 & 0,24 & 7 & 65 & 64 & 3,1 & 1,9 & 2,10 & 0,26 & 0.30 & 0,24 & 22,6 \\
\hline
\end{tabular}

Keterangan : Data pada tabel diatas merupakan hasil analisis laboratorium dan tidak dilakukan analisa statistik 
Berdasarkan hasil analisis tanah (Tabel 1) menujukkan bahwa kemasaman tanah $(\mathrm{pH})$ sebelum dipupuk 3,9 setelah diberi perlakuan $\mathrm{pH}$ mengalami peningkatan antara 4,10 - 4,26. Nilai pH terendah terjadi pada perlakuan pupuk anorganik (NPK) yaitu 4,0. Pemberian pupuk organik (bokashi) pH tanah menjadi 4,10 dan perlakuan kombinasi pupuk anorganik (NPK) dan organik (bokashi) pH-nya menjadi 4,26. Hal ini menunjukkan bahwa pemupukan meningkatkan $\mathrm{pH}$ tanah penambahan pupuk organic mampu memperbaiki dan meningkatkan $\mathrm{pH}$ tanah lebih baik disbanding pupuk anorganik. Peningkatan $\mathrm{pH}$ tanah dari 3,9 menjadi 4,26. akibat pemupukan bokashi, yang mana bokashi ini mengandung pupuk kandang dan bahan organik yang difermentasi dengan efektif mikroorganisme. Fermentasi ini akan menghasillkan glukosa, ester, asam nukleat, alkohol, ester, asam amino, hormone, enzim, vitamin, dan antioksidan. Diduga hasil-hasil de-ionisasi ini akan mengikat ion $\mathrm{H}^{+}$ sehingga konsentrasi ion $\mathrm{H}^{+}$menurun. Hal ini akan mengakibatkan konsentrasi ion $\mathrm{OH}^{-}$ meningkat atau $\mathrm{pH}$ tanah meningkat. Meskipun demikian, $\mathrm{pH}$ tanah tersebut masih lebih rendah dibandingkan $\mathrm{pH}$ yang diperlukan tanaman Ubi Kayu untuk dapat tumbuh optimum yaitu $>5,5$.

Karbon organik (C-org.) pada tanah sebelum perlakuan (tanah awal) 1,50 persen. Setelah perlakuan pemupukan mengalami peningkatan menjadi 1,70 - 1,82 persen. Nitrogen $(\mathrm{N})$ total pada tanah awal 0,13 persen setara dengan $26 \mathrm{~kg} \mathrm{~N}$ per hektar. Sedangkan kebutuhan tanaman ubi kayu terhadap unsur $\mathrm{N}$ sebesar $90 \mathrm{~kg}$ per hektar, sehingga kekurangan sebesar $64 \mathrm{~kg}$.jumlah ini dapat dipenuhi dengan jumlah pupuk (anorganik atau organik) yang diberikan. Hal ini ditunjukkan oleh data bahwa perlakuan pemupukan anorganik (NPK) dan organik (bokashi) meningkatkan ketersediaan nitrogen dari 0,11 hingga 0,24 persen setara dengan $22 \mathrm{~kg} \mathrm{~N}$ hingga $48 \mathrm{~kg} \mathrm{~N}$ per hektar.

Unsur Fosfor $\left(\mathrm{P}_{2} \mathrm{O}_{5}\right)$ meningkat dalam tanah setelah pemberian pupuk anorganik ataupun organik. Kandungan $\mathrm{P}_{2} \mathrm{O}_{5}$ dalam tanah sebesar 8 ppm setara dengan 18,2 kg fosfor per hektar. Sedangkan kebutuhan fosfor untuk tanaman ubi kayu sebesar $200 \mathrm{~kg}$ per hektar. Pemberian pupuk organik dan anorganik serta kombinasinya meningkatkan fosfor dalam tanah. Fosfor dalam tanah setelah panen berkisar antara $28-72$ ppm setara dengan 64,1 kg fosfor per hektar. Sesuai dengan pendapat Nurhayati Hakim; dkk, (1986), melalui proses pelapukan fosfor organik dapat diubah menjadi fosfor anorganik seperti $\mathrm{H}_{2} \mathrm{PO}_{4}$ dan $\mathrm{HPO}_{4}$ melalui proses pelapukan sehingga dapat diserap tanaman. Fahmi, dkk., (2009) menambahkan peran fosfor dianggap sebagai "key of life" pada tanaman karena mempunyai fungsi penting dalam proses fotosintesis, respirasi, transfer energy seperti adenosine trifosfat (ATP) dan adenosine difosfat (ADP), penyimpanan energi, pembelahan dan pembesaran sel serta proses-proses didalam tanaman lainnya (Rosmarkun dan Yuwono, 2002). 
Hadi Suwito (2007) yang menyatakan bahwa bahan organik yang sudah mengalami perombakan menjadi pupuk dapat menyediakan nitrogen bagi tanaman. Ditambahkan oleh Novizan (2005) nitrogen yang berasal dari bahan organik dapat dimanfaatkan oleh tanaman setelah terdekomposisi yang melibatkan aktivitas mikroorganisme tanah. Setyamidjaya (1986), nitrogen berperan untuk merangsang pertumbuhan vegetatif yaitu menambah tinggi tanaman membuat tanaman menjadi hijau karena banyak mengandung butir-butir hijau daun (khlorofil) yang penting dalam proses fotosintesis untuk pembentukan karbohidrat, protein dan lemak.

Peranan unsur nitrogen apabila diserap oleh tanaman akan meningkatkan pembentukan asam amino dalam tanaman. Asam amino tersebut di ranslokasikan ke jaringan meristem untuk digunakan dalam pembelahan sel.

Unsur Kalium $\left(\mathrm{K}_{2} \mathrm{O}\right)$ meningkat dalam tanah setelah pemberian pupuk bokashi dan NPK. Kandungan $\mathrm{K}_{2} \mathrm{O}$ meningkat dari 30-69 ppm. Peranan unsur kalium adalah meningkatkan resistensi terhadap penyakit, mencegah kerebahan tanaman, dan didalam tubuh tanaman sebagai katalisator dalam metabolisme karbohidrat.

\section{Hasil Analisis Jaringan Tanaman}

Hasil analisis jaringan tanaman yaitu kandungan unsur hara dari daun muda tanaman yang tercantum pada Tabel 2 di bawah ini.

Tabel 2. Hasil Analisis Jaringan Daun Ubi Kayu

\begin{tabular}{|c|c|c|c|c|c|c|c|c|}
\hline \multicolumn{2}{|c|}{ Kode } & C- organik & $\mathrm{N}$ - total & \multirow{2}{*}{$\mathrm{C} / \mathrm{N}$} & $P$ & $\mathrm{~K}$ & $\mathrm{Ca}$ & $\mathrm{Mg}$ \\
\hline Lapang & Lab & & & & \multicolumn{4}{|c|}{$\%$ total } \\
\hline v1p0 & 8110 & 45,2 & 5,0 & 9,5 & 0,34 & 0.75 & 0,37 & 0.16 \\
\hline v2p0 & 8111 & 44,9 & 4,7 & 9,6 & 0,32 & 0,76 & 0,37 & 0.15 \\
\hline v3p0 & 8112 & 45,0 & 4,9 & 9,5 & 0,32 & 0,76 & 0,38 & 016 \\
\hline v1p1 & 8113 & 50,6 & 5,1 & 9,5 & 0,36 & 0,88 & 0,37 & 0.17 \\
\hline v2p1 & 8114 & 51,5 & 5,4 & 9,8 & 0.37 & 0,87 & 0,38 & 0.17 \\
\hline v3p1 & 8115 & 51.3 & 5,4 & 9,7 & 0,36 & 0,86 & 0,39 & 0.16 \\
\hline v1p2 & 8116 & 53,0 & 5,2 & 10,0 & 0,38 & 0,90 & 0,40 & 0,19 \\
\hline v2p2 & 8117 & 54,0 & 5,2 & 9,9 & 0,37 & 0,91 & 0,41 & 0.20 \\
\hline v3p2 & 8118 & 54,0 & 5,5 & 9,8 & 0,37 & 0,91 & 0,40 & 0.20 \\
\hline v1p3 & 8119 & 55.2 & 5.4 & 9,7 & 0,39 & 0,93 & 0,42 & 0.20 \\
\hline v2p3 & 8120 & 54.6 & 5.7 & 9,7 & 0,38 & 0,92 & 0,42 & 0.21 \\
\hline v3p3 & 8121 & 55.4 & 5.8 & 9,8 & 0,38 & 0,93 & 0,43 & 0.22 \\
\hline
\end{tabular}

Keterangan: Data pada tabel diatas merupakan hasil analisis laboratorium dan tidak dilakukan analisa statistik

Data hasil analisis jaringan daun tanaman ubi kayu tersebut (Tabel 2) menunjukkan bahwa antara tanaman yang dipupuk baik organik maupun anorganik serta kombinasinya dibandingkan dengan tanaman tidak dipupuk (kontrol), terdapat kecendrungan berbeda. Kandungan nitrogen pada tanaman yang tidak dipupuk (kontrol) sebesar 4,9 persen, sedangkan yang dipupuk anorganik cenderung meningkat yaitu rata-rata sebesar 5,3 persen, dan yang dipupuk dengan pupuk organik meningkat rata-rata sebesar 5,6 persen. $\mathrm{Hal}$ ini disebabkan karena pemberian $\mathrm{N}$ menyebabkan ketersediaan $\mathrm{N}$ lebih tinggi sehingga absorpsi unsur tersebut cenderung lebih meningkat pula dalam proses metabolisme 
tanaman. Nitrogen diserap tanaman dalam bentuk $\mathrm{NO}_{3}^{-}$dan $\mathrm{NH}_{4}{ }^{+}$kemudian dirubah menjadi gugusan asam amino, selanjutnya membentuk protein dan asam nukleat. Dengan meningkatnya kandungan protein dalam protoplasma akan meningkatkan ukuran sel dan jaringan. Akibatnya tanaman akan tumbuh berkembang, dalam bentuk pertumbuhan vegetatif dan generatif yaitu masing-masing dalam bentuk akar, batang, daun dan umbi.

Perbandingan C/N pada jaringan tanaman ubi kayu menunjukkan angka 9,5-10. Hal ini menunjukkan bahwa kandungan nitrogen dalam jaringan daun cukup besar atau $\mathrm{C} / \mathrm{N}$ relatif rendah.Hal ini berarti ada korelasi antara kandungan nitrogen dalam tanah dengan kandungan nitrogen dalam jaringan tanaman dalam hal ini jaringan daun.

Antara tanaman kontrol dan tanaman perlakuan, pemupukan $\mathrm{P}$ ternyata absorpsinya tidak berbeda, yaitu kontrol 0,33 persen dan tanaman yang diberi perlakuan pupuk anorganik 0,36 persen dan organik 0,37 persen. Kemungkinan absorpsi unsur fosfor hanya mampu diabsorpsi sebesar 30 persen dari pupuk yang diberikan. Unsur fosfor lainnya dalam bentuk tidak tersedia yaitu difiksasi oleh koloid tanah/mineral liat atau unsur Al, atau Fe.Fosfor diserap tanaman dalam bentuk $\mathrm{H}_{2} \mathrm{PO}_{4}^{-}$dan $\mathrm{HPO}_{4}^{-}$dan dirubah menjadi asam nukleat, fosfolipida dan fitin.Untuk tanaman ubi kayu fosfor berperan untuk perkembangan akar.Selanjutnya akar tanaman ini berkembang menjadi umbi.

Fosfor meningkatkan proses pembelahan sel, pembentukan sel, pembetukan lemak serta albumin. Juga merangsang pembentukan bunga, buah dan biji serta memperkuat batang, akar dan meningkatkan daya tahan tanah terhadap penyakit (Harjowigeno S, 2007).

Hasil analisis jaringan tanaman (Tabel 2) menunjukkan bahwa absorpsi unsur kalium oleh tanaman ubi kayu yang diberi perlakuan pemupukan anorganik $(0,87 \%)$ dan organik cenderung lebih tinggi $(0,90 \%)$ dibandingkan unsur kalium pada tanaman ubi kayu yang tidak dipupuk $(0,76 \%)$. Hal ini disebabkan oleh karena unsur kalium pada tanah yang dipupuk anorganik dan organik ketersediannya menjadi lebih tinggi atau melebihi kebutuhan optimal dari tanaman artinya ada korelasi antara absorpsi unsur kalium oleh tanaman dengan ketersediaannya dalam tanah. Unsur kalium berperan mendorong perkembangan sitoplasma dan sebagai katalisator dalam pembentukan karbohidrat, memperkuat batang dan perkembangan akar. Menurut Sarwono (1995), bahwa unsur K memiliki fungsi sebagai katalisator untuk pembuatan pati, pembukaan stomata, meningkatkan daya tahan terhadap kekeringan, hama penyakit, mempengaruhi unsurunsur hara lain dan perkembangan akar.

Hasil analisis jaringan tanaman (Tabel 2) menunjukkan bahwa absorpsi unsur $\mathrm{Ca}$ dan Mg oleh tanaman ubi kayu yang diberi perlakuan pupuk anorganik dan organik cenderung meningkat masing-masing $0,38 \%$ dan $0,17 \%$ dibandingkan dengan yang tidak dipupuk yaitu sebesar $0,37 \%$ dan $0,15 \%$. Hal ini disebabkan adanya peningkatan unsur $\mathrm{Ca}$ 
dan Mg dalam tanah setelah diberi perlakuan pemupukan.Di dalam jaringan tanaman unsur ini terdapat pada bagian pada bagian daun tanaman, khususnya pada dinding sel dalam bentuk Ca' pektat.

Unsur Mg diserap tanaman dalam bentuk ion $\mathrm{Mg}^{++}$dan unsur ini berfungsi sebagai penyusun khlorofil dalam daun, yang terdapat pada pusat molekul sehingga peranan unsur Mg pada tanaman sangat penting. Jika tanaman kekurangan unsur tersebut maka tanaman tidak mampu melaksanakan proses fotosintesis. Unsur Mg bersama $P$ berfungsi untuk mengaktifkan system enzim tanaman.

\section{Tinggi Tanaman}

Respon pertumbuhan 3 varietas ubi kayu terhadap pemberian pupuk anorganik (NPK) dan organik (bokashi pupuk kandang) serta kombinasinya terhadap tinggi tanaman tercantum pada Tabel 3.

Tabel 3. Pengaruh perlakuan pupuk anorganik dan organik serta kombinasinya terhadap tinggi tanaman saat panen pada tiga varietas ubi kayu $(\mathrm{cm})$

\begin{tabular}{|c|c|c|c|c|c|}
\hline V ( Main plot) & $\mathbf{P}$ (Sub plot) & $\mathbf{1}$ & $\mathbf{2}$ & $\mathbf{3}$ & Total \\
\hline \multirow{4}{*}{$\mathrm{v} 1$} & $\mathrm{p} 0$ & 290 & 320 & 327 & $\mathbf{9 3 7}$ \\
\cline { 2 - 6 } & $\mathrm{p} 1$ & 280 & 245 & 345 & $\mathbf{8 7 0}$ \\
\cline { 2 - 6 } & $\mathrm{p} 2$ & 360 & 350 & 325 & $\mathbf{1 0 3 5}$ \\
\cline { 2 - 6 } & $\mathrm{p} 3$ & 335 & 325 & 335 & $\mathbf{9 9 5}$ \\
\hline \multirow{4}{*}{ v2 } & $\mathrm{p} 0$ & 225 & 370 & 316 & $\mathbf{9 1 1}$ \\
\cline { 2 - 6 } & $\mathrm{p} 1$ & 285 & 295 & 357 & $\mathbf{9 3 7}$ \\
\cline { 2 - 6 } & $\mathrm{p} 2$ & 295 & 294 & 320 & $\mathbf{9 0 9}$ \\
\cline { 2 - 6 } & $\mathrm{p} 3$ & 340 & 320 & 330 & $\mathbf{9 9 0}$ \\
\hline \multirow{4}{*}{ v3 } & $\mathrm{p} 0$ & 315 & 255 & 310 & $\mathbf{8 8 0}$ \\
\cline { 2 - 6 } & $\mathrm{p} 1$ & 310 & 280 & 290 & $\mathbf{8 8 0}$ \\
\cline { 2 - 6 } & $\mathrm{p} 2$ & 280 & 345 & 290 & $\mathbf{9 1 5}$ \\
\cline { 2 - 6 } & $\mathrm{p} 3$ & 300 & 330 & 312 & $\mathbf{9 4 2}$ \\
\hline \multicolumn{2}{|c|}{ JUMLAH } & $\mathbf{3 6 1 5}$ & $\mathbf{3 7 2 9}$ & $\mathbf{3 8 5 7}$ & $\mathbf{1 1 2 0 1}$ \\
\hline
\end{tabular}

Hasil analisis statistik interaksi antara dosis pupuk dan varietas terhadap tinggi tanaman ubi kayu tercantum pada Tabel 4, dan dapat digambarkan dalam bentuk kurva atau diagram batang atau histogram dibawah ini (Gambar 1).

Tabel 4. Interaksi Antara Dosis Pupuk Dan Varietas Terhadap Tinggi Tanaman Ubi Kayu (cm)

\begin{tabular}{|c|c|c|c|c|}
\hline \multirow{2}{*}{ Perlakuan } & \multicolumn{3}{|c|}{ Varietas } & \multirow{2}{*}{ Rata-Rata } \\
\hline & V1 & v2 & v3 & \\
\hline p0 & 312.33 & 303.67 & 293.33 & 303.11 \\
\hline p1 & 290,00 & 312.33 & 293,33 & 298,56 \\
\hline p2 & 345.00 & 303.00 & 305.00 & 317.67 \\
\hline p3 & 313.67 & 330.00 & 314.00 & 325.22 \\
\hline Total & 319.75 & 312.25 & 301.42 & 311.14 \\
\hline
\end{tabular}




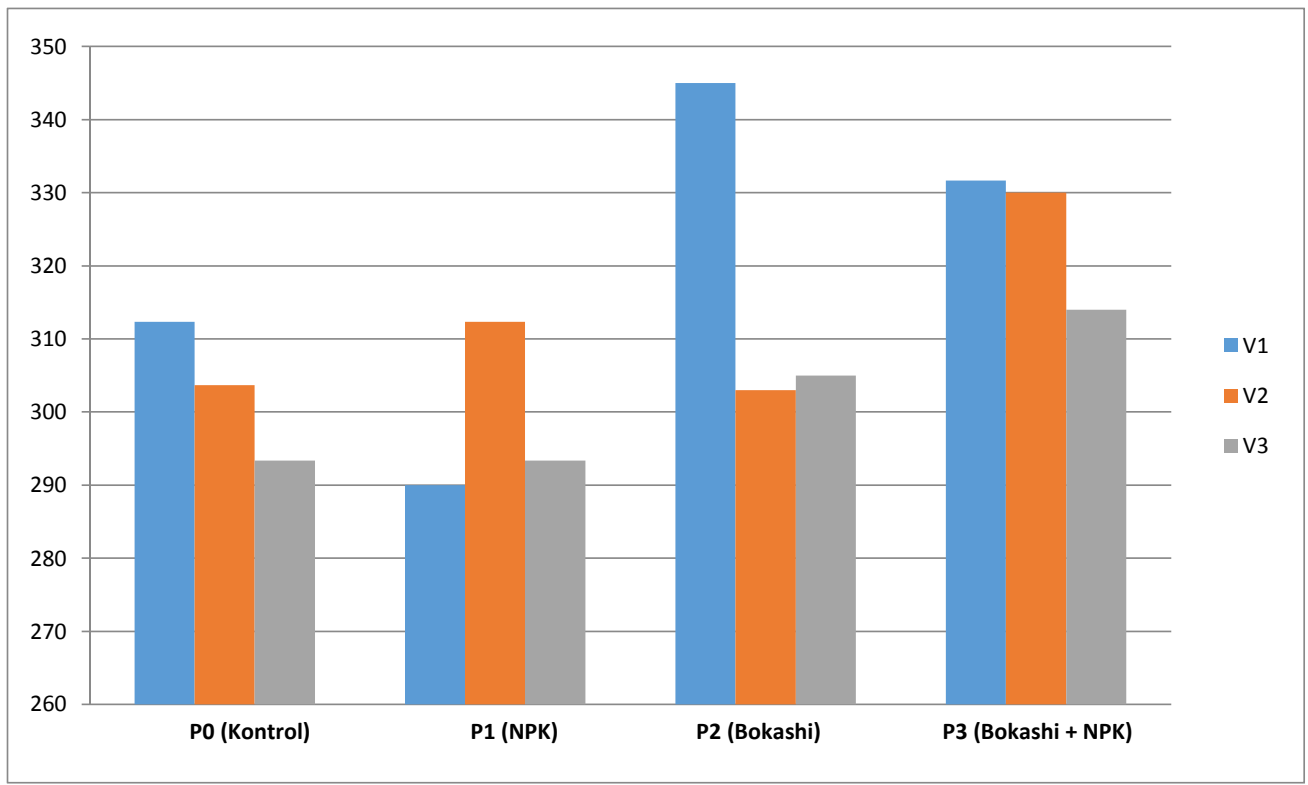

Gambar 1. Histogram Respon pertumbuhan 3 Varietas Ubi Kayu Terhadap Pemberian Pupuk Anorganik (NPK) Dan Organik (Bokashi Pupuk Kandang) Serta Kombinasinya Terhadap Tinggi Tanaman.

Dari hasil analisis statistik (Tabel 3 dan 4) pada tinggi tanaman menunjukkan bahwa pupuk anorganik (P1-NPK) dan organik (P2-bokashi) serta kombinasinya (P3NPK+bokashi) tidak berpengaruh nyata dibandingkan dengan kontrol (P0). Antara ketiga varietas tersebut yaitu ada kecendrungan tinggi tanaman ubi kayu varietas Kasesat menunjukkan relatif lebih tinggi dibandingkan varietas Darul Hidayah dan varietas Gajah pada semua perlakuan.Kemungkinan perbedaan tinggi tanaman disebabkan oleh sifat genetis tanaman, dimana tanaman ubi kayu varietas Kasesat mempunyai fenotipe lebih tinggi dari varietas yang lainnya.

Pengaruh pemupukan baik anorganik (NPK) maupun organik (bokashi) serta kombinasinya (anorganik dan organik) berpengaruh nyata. Berarti penambahan pupuk akan menambah ketersediaan unsur hara dalam tanah. Merdekawati; dkk (2014) menambahkan pupuk bokashi yang berarti hasil fermentasi bahan organik dengan mikroorganisme (EM-4) yang merupakan kultur campuran dari sejumlah mikroorganisme yang menguntungkan, yaitu membantu memperbaiki biologis tanah dan membantu penyerapan unsur hara.

\section{Berat umbi per hektar}

Respon hasil berat umbi 3 varietas ubi kayu terhadap pemberian pupuk anorganik (NPK) dan organik (bokashi pupuk kandang) serta kombinasinya tercantum pada Tabel 5. Hasil analisis statistik interaksi antara dosis pupuk dan varietas terhadap berat umbi per hektar tercantum pada Tabel 6 dan digambarkan dalam bentuk diagram batang (Gambar 2). 
Tabel 5. Pengaruh perlakuan pupuk anorganik dan organik serta kombinasinya terhadap berat umbi per hektar pada tiga varietas ubi kayu (ton).

\begin{tabular}{|c|c|c|c|c|c|c|}
\hline \multirow{2}{*}{ Varietas } & \multirow{2}{*}{$\begin{array}{c}\text { Perlakuan } \\
\text { Pemupukan }\end{array}$} & \multicolumn{3}{|c|}{ Ulangan (kelompok) } & \multirow{2}{*}{ Total } & \multirow{2}{*}{ Rata-Rata } \\
\hline & & 1 & 2 & 3 & & \\
\hline \multirow{5}{*}{ v1 } & $\mathrm{p} 0$ & 33,92 & 27,75 & 38,0 & 99,67 & 33,22 \\
\hline & $\mathrm{p} 1$ & 38,65 & 28,38 & 42,5 & 109,53 & 36,51 \\
\hline & p2 & 34,0 & 47,13 & 50,0 & 131,13 & 43,71 \\
\hline & p3 & 53,0 & 45,63 & 42,63 & 141,26 & 47,09 \\
\hline & Rata-rata & & & & & 40,13 \\
\hline \multirow{5}{*}{ v2 } & p0 & 35,0 & 31,5 & 34,38 & 100,88 & 33,63 \\
\hline & $\mathrm{p} 1$ & 42,25 & 40,25 & 30,50 & 113 & 37,67 \\
\hline & $\mathrm{p} 2$ & 45,13 & 31,84 & 35,25 & 112,22 & 37,41 \\
\hline & p3 & 48,50 & 45,63 & 52,0 & 146,13 & 48,71 \\
\hline & Rata-Rata & & & & & 39,35 \\
\hline \multirow{5}{*}{ v3 } & p0 & 24,0 & 38,0 & 34,0 & 96 & 32,00 \\
\hline & $\mathrm{p} 1$ & 49,25 & 40,50 & 45,0 & 134,75 & 44,92 \\
\hline & p2 & 32,75 & 49,7 & 47,50 & 129,95 & 43,32 \\
\hline & p3 & 66,51 & 53,0 & 46,75 & 166,26 & 55,42 \\
\hline & Rata-Rata & & & & & 43,91 \\
\hline & & 502,96 & 479,31 & 498,51 & 1480,78 & \\
\hline
\end{tabular}

Tabel 6. Interaksi Antara Dosis Pupuk Dan Varietas Terhadap Berat Umbi Per Hektar (ton)

\begin{tabular}{|c|c|c|c|c|}
\hline Perlakuan & v1 & v2 & v3 & Total \\
\hline p0 & 33.22 & 33.63 & 32.00 & $\mathbf{3 2 . 9 5} \mathbf{c}$ \\
\hline p1 & 36.51 & 37.67 & 44.92 & $\mathbf{3 9 . 7 0} \mathbf{b}$ \\
\hline p2 & 40.38 & 37.41 & 43.32 & $\mathbf{4 0 . 3 7} \mathbf{b}$ \\
\hline p3 & 47.09 & 48.71 & 55.42 & $\mathbf{5 0 . 4 1} \mathbf{a}$ \\
\hline Total & $\mathbf{3 9 . 3 0}$ & $\mathbf{3 9 . 3 5}$ & $\mathbf{4 3 . 9 1}$ & $\mathbf{4 0 . 8 6}$ \\
\hline
\end{tabular}

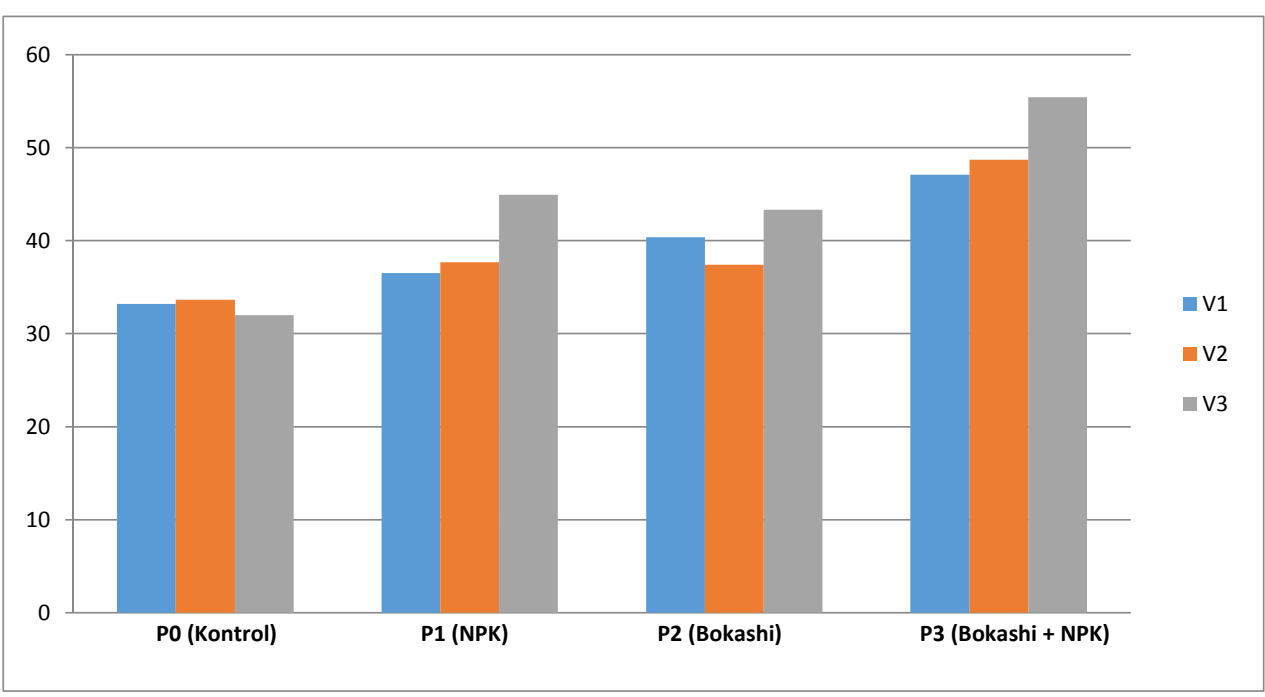

Gambar 2. Histogram Respon Hasil Berat Umbi 3 Varietas Ubi Kayu Terhadap Pemberian Pupuk Anorganik (NPK) Dan Organik (Bokashi Pupuk Kandang) Serta Kombinasinya.

Dari hasil analisis statistik (Tabel 5 dan 6) pada berat umbi per hektar menunjukkan bahwa pupuk anorganik (P1) menghasilkan 39,70 ton per hektar dan organik (P2) 40,37 
ton per hektar serta kombinasinya (P3) 50,31 ton/hektar berpengaruh nyata dibandingkan dengan kontrol (P0) yaitu 32,95 ton/hektar pada semua varietas, yaitu pemupukan anorganik NPK (P1), pupuk organik (P2) dan kombinasinya (P3) masing-masing lebih tinggi 14,41\%, 22,52\%, dan 53\% dibandingkan kontrol (P0). Produksi umbi varietas Kasesat (V1) 39,30 ton, varietas Darul Hidayah (V2) 39,35 ton/hektar dan Gajah (V3) 43,91 ton per hektar. Antara ke tiga tidak berpengaruh nyata, tetapi varietas cenderung lebih tinggi produksinya sebesar $11,37 \%$ dibandingkan kedua varietas Kasesat dan Darul Hidayah. Hal ini disebabkan karena pemberian pupuk anorganik (NPK) akan menambah ketersediaan unsur hara dalam tanah, kemudian ditambah pupuk organik (bokashi).

Wididana (1993) dan Tufaila, dkk (2014) menambahkan mengandung mikroorganisme fermentasi dan fotosintetik yang terdiri dari bakteri asam laktat (lactobaccilus, sp) bakteri fotosintetik (Rhodo pseudomonas sp), Actininomycetes sp, Streptomycetes sp dan ragi (Yeast), sehingga dengan pemberian NPK dan bokashi mampu menambah asam amino, gula, ester, ensim, alcohol dan vitamin yang dibutuhkan tanaman ubi kayu. Akibatnya tanaman yang dipupuk produksi umbi meningkat.Tetapi walaupun pupuk anorganik dan organik sudah diberikan, nampaknya unsur hara yang ada tidak diserap secara optimal.Hal ini kemungkinan pengolahan tanah kurang intensif sehingga kurang menciptakan lingkungan yang ideal atau optimal, yaitu aerasi atau tata udara dan drainase atau tata air tidak seimbang sehingga kurang memenuhi persyaratan tumbuh bagi perkembangan tanaman akar-akar ubi kayu.Hal ini mengakibatkan rizofer perakaran terbatas maka penyerapan unsur hara pun terbatas, sehingga jumlah dan berat umbi terbatas.

Tabel 7. Pengaruh perlakuan pupuk anorganik dan organik serta kombinasinya terhadap berat biomassa per hektar pada tiga varietas ubi kayu (ton/hektar)

\begin{tabular}{|c|c|c|c|c|c|}
\hline V (Main Plot) & P (Sub Plot) & 1 & 2 & 3 & Total \\
\hline \multirow{4}{*}{$\mathrm{v} 1$} & $\mathrm{p} 0$ & 55.17 & 44.63 & 53.25 & 153.05 \\
\hline & $\mathrm{p} 1$ & 59.88 & 47.88 & 65.58 & 173.34 \\
\hline & $\mathrm{p} 2$ & 46.50 & 69.63 & 70.00 & 186.13 \\
\hline & p3 & 86.01 & 68.13 & 62.76 & 216.90 \\
\hline \multirow{4}{*}{ v2 } & p0 & 49.25 & 60.25 & 65.63 & 175.13 \\
\hline & $\mathrm{p} 1$ & 83.01 & 61.05 & 54.50 & 198.56 \\
\hline & p2 & 88.88 & 60.59 & 59.51 & 208.98 \\
\hline & p3 & 76.26 & 91.28 & 83.92 & 251.46 \\
\hline \multirow{5}{*}{ v3 } & $\mathrm{p} 0$ & 62.25 & 53.13 & 47.75 & 163.13 \\
\hline & $\mathrm{p} 1$ & 87.26 & 66.76 & 71.26 & 225.28 \\
\hline & p2 & 54.63 & 78.51 & 70.63 & 203.77 \\
\hline & p3 & 91.26 & 80.26 & 69.00 & 240.52 \\
\hline & JUMLAH & 840.36 & 782.10 & 773.79 & 2396.25 \\
\hline
\end{tabular}




\section{Berat Biomassa ( batang + daun ) per hektar}

Pengaruh perlakuan pupuk anorganik dan organik (bokashi) serta kombinasinya terhadap berat biomassa per hektar pada tiga varietas ubi kayu tercantum pada Tabel 7 .

Hasil analisis statistik interaksi antara dosis pupuk dan varietas terhadap berat biomassa per petak tercantum pada Tabel 8 dan digambarkan dalam bentuk diagram batang ( Gambar 3).

Tabel 8. Interaksi antara dosis pupuk dan varietas terhadap berat biomassa per hektar (ton)

\begin{tabular}{|c|c|c|c|c|}
\hline Perlakuan & v1 & v2 & v3 & Total \\
\hline p0 & 51.02 & 58.38 & 54.38 & $\mathbf{5 4 . 5 9 c}$ \\
\hline p1 & 57.78 & 66.19 & 75.09 & $\mathbf{6 6 . 3 5} \mathrm{bc}$ \\
\hline p2 & 62.04 & 69.66 & 67.92 & $\mathbf{6 6 . 5 4} \mathrm{b}$ \\
\hline p3 & 72.30 & 83.82 & 80.17 & $\mathbf{7 8 . 7 6} \mathrm{a}$ \\
\hline Total & $\mathbf{6 0 . 7 9} \mathrm{b}$ & $\mathbf{6 9 . 5 1} \mathrm{a}$ & $\mathbf{6 9 . 3 9} \mathrm{a}$ & $\mathbf{6 6 . 5 6}$ \\
\hline
\end{tabular}

Keterangan: Angka yang diikuti oleh huruf yang sama pada baris dan kolom yang sama menyatakan tidak berbeda nyata pada BNT 5\%.( $\mathrm{V}=14,64 ; \mathrm{P}=19,55)$

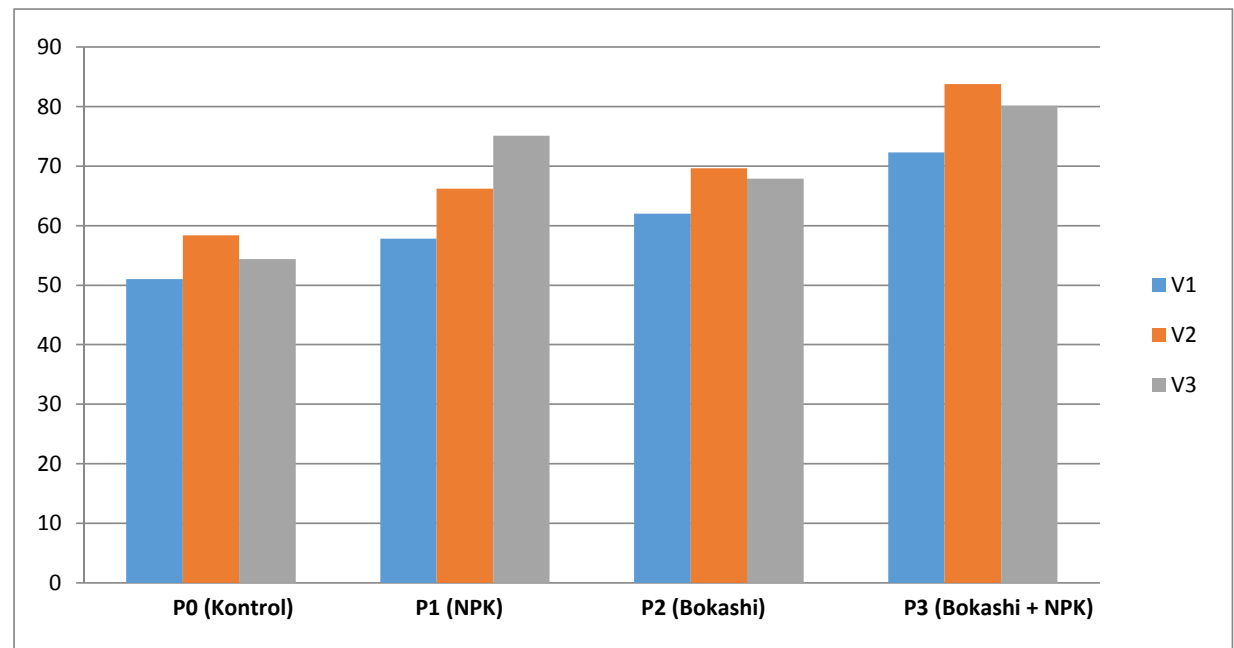

Gambar 3. Histogram Respon Hasil Berat Biomassa 3 Varietas Ubi Kayu Terhadap Pemberian Pupuk Anorganik (NPK) Dan Organik (Bokashi Pupuk Kandang) Serta Kombinasinya

Dari hasil analisis statistik (Tabel 7 dan 8) pada berat biomassa per hektar menunjukkan bahwa pupuk anorganik (P1) dan organik (P2) tidak berpengaruh nyata dibandingkan kontrol, sedangkan kombinasinya (P3) berpengaruh nyata dibandingkan dengan kontrol (P0) pada semua varietas. Pupuk anorganik NPK (P1), pupuk organik (P2) dan kombinasinya (P3) masing-masing lebih tinggi 27\%, 40\%, dan 36\% dibandingkan kontrol (P0). Antara varietas yaitu Darul Hidayah (V2) dan Gajah (V3) lebih tinggi secara nyata masing-masing 36\% dan 31\% dibandingkan varietas Kasesat (V1) tetapi antara varietas Darul Hidayah (V2) dan Gajah (V3) tidak berpengaruh nyata.

Dari hasil analisis statistiK (Tabel 7 dan 8) pada berat bimassa per hektar menunjukkan bahwa pupuk anorganik (P1) dan organik (P2) tidak berpengaruh nyata dibandingkan kontrol, sedangkan kombinasinya (P3) berpengaruh nyata dibandingkan dengan control (P0) pada semua varietas. Pupuk anorganik NPK (P1), Pupuk organik (P2) 
dan kombinasinya (P3) masing - masing lebih tinggi 27\%, 40\% dan 36\% dibandingkan kontrol (P0). Antara varietas yaitu Darul Hidayah (V2) dan Gajah (V3) lebih tinggi secara nyata masing - masing 36\% dan 31\% dibandingkan varietas Kasesat (V1) tetapi antara varietas Darul Hidayah (V2) dan Gajah (V3) tidak berpengaruh nyata.

\section{$4 \quad$ Kesimpulan dan Saran}

\section{Kesimpulan}

Berdasarkan hasil-hasil analisis dan pembahasan dapat disimpulkan sebagai berikut:

1. Pemupukan anorganik (NPK), organik (bokashi) dan kombinasinya mampu menghasilkan umbi masing-masing 39,70 ton/hektar, 40,37 ton per hektar dan 50.41 ton/hektar, sedangkan kontrol 32,95 ton/hektar atau perlakuan pemupukan tersebut dapat meningkatkan produksi umbi masing-masing 14,41\%; 22,52 \% dan 52,99 \% dibandingkan kontrol. Kombinasi pupuk anorganik (NPK) dan organik (bokashi) meningkatkan umbi secara nyata terhadap ketiga perlakuan lainnya.

2. Antara ketiga varietas ubi kayu tidak berpengaruh nyata. Verietas Gajah menunjukkan produksi relative lebih tinggi $11,73 \%$ dibandingkan kedua varietas lainnya yaitu varietas Kasesat (V1) dan Darul Hidayah (V2).

\section{Saran}

Untuk memperoleh produksi umbi yang maksimal dianjurkan pemupukan kombinasi anorganik (NPK) $800 \mathrm{~kg} /$ hektar dan organik (bokashi) sebesar 20 ton/hektar yaitu berat umbi 50,41 ton/hektar. Untuk memperoleh produksi umbi ubi kayu maksimal dianjurkan menggunakan varietas Gajah dengan produksi 50,41 ton/hektar. Untuk meningkatkan produksi umbi perlu pengolahan tanah lebih dalam sekitar $40 \mathrm{Cm}$ agar pertumbuhan dan perkembangan umbi lebih maksimal.

\section{Daftar Pustaka}

Aritonang A.R dan Lasiwa C.D. (2011).Aplikasi Pupuk Organik Cair Terhadap Pertumbuhan dan Produksi Tanaman Sawit. Jurnal Agrisistem 7(1): 47-57

Fahmi, A., Radjaguguk, B., dan Purwanto, B.H. (2009). Kelarutan Fosfat dan Ferro pada Tanah Sulfat Masam yang diberi Bahan Organik Jerami Padi. Jurnal Tanah Tropik. 14(2):119-125. http://journal.unila.ac.id/index,php/tropicalsoil/artick/view/598. 3 februari 2017

Hadi Suwito, S. (2007). Membuat Pupuk Kompas Cair. PT Agio Media Pustaka, Jakarta

Hakim, N, M. Y. Nyakpa, A.M Lubis, S.G. Nugioko, M.A Diha, G.B. Hong dan H.H bailey (1986). Dasar-dasar IImu Tanah. Universitas Lampung, Lampung.

Harjowigono. (2007). IImu Tanah. Akademika Presindo, Jakarta

Kimaryo, VM, G.A Masawe, N.A Olasupo, W H Holzapfel. (2000). The Use of Statin Culture in the Jurmentation of Cassava Foz the Production of "Kivunde A Traditional Tanzanian Food Product int of Food Microb 
Merdekawati, Agus, Linda, R., dan Mukarin. (2014). Pertumbuhan Cabai (Capsicum annum L) dengan pemberian Gigaspora margaria dan Bokashi Jerami Padi Pada Tanah Gambut. Jurnal Protobiout, Universitas Tanjungpura. Pontianak. http://www.ejurnal.com/search?q=jurnal+bokashi+jerami+padi\&max-result=20\&by-date=true. 5 Maret 2017

Mulyanti, S.S, Made, U., dan Wahyudi, I. 2015. Pengaruh Pemberian Berbagai Jenis Bokashi Terhadap Pertumbuhan dan Hasil Tanaman Jagung Manis (Zea mays saccarata). E-jurnal Agrotekbis. 3(5): 592-601. Novizan, 2005.Penunjuk Pemupukan yang Efektif. Agromedia Pustaka. Jakarta

Rama Prihandana. (2007). Bioetanol Ubi Kayu: Bahan-bahan Masa Depan. Jakarta

Rosmarkum A dan N.W Yuwono. (2002). Ilmu Kesuburan Tanah. Kawasiwo, Yogyakarta

Setyamidjaya, D. (1986). Pupuk dan Pemupukan. Simplek, Jakarta

Tufaila, M., Yusrina, dan Alam, S. (2014). Pengaruh Pupuk Bokashi Kotoran Sapi Terhadap Pertumbuhan dan Produksi Padi sawah Pada Ultisol Puosa Jaya Kecamatan Konda, konawe Selatan. Jurnal Agroteknas. 4(1):18-25.

Wididana G N dan T Huga. (1993). Penuntun bercocok Tanam Padi dengan Mikroorganisme 4 (EM4) Seri Pertanian Akrab Lingkungan Teknologi dengan Teknologi Effektive.

Widida,G.N. (1993). Peranan Effective Microorganisme 4 dalam meningkatkan kesuburan dan Produktivitas Tanah. Indonesia Kyusei Nature Farwing

Yibo, L. H. (2010). Antioxida Phenolic Conpound of Cassava (Manihot esculenta from Hainan Moleculis) 16.11015-7-10107 